\section{Peer review loses out in congressional cutting spree}

Washington. A battle between the US Congress and President George Bush over who is responsible for waste in the federal budget has turned into a competition to kill science projects with titles that politicians consider to kill 31 comically named projects, angering research groups and ignoring the fact that most had passed muster with the scientific community.

In March, Bush sent Congress a list of 246 projects - many of them science orientated - that he deemed wasteful or duplicative. High on the list were projects that Congress had inserted into the budget through a process known as earmarking or 'pork'. Eliminating all the offenders from the 1992 budget would save $\$ 3,600$ million, Bush said.

Last week, Congress responded with legislation to save a similar amount. But most of the projects Congress selected for the axe, in separate bills, were those proposed by the administration itself. Whereas the administration singled out such obscure agricultural research projects as "Leafy spurge biocontrol" and "Lowbush blueberry research", Congress simply used the 'silly title rule' that former Senator William Proxmire had followed for more than a decade in choosing his notorious "Golden Fleece Awards".

The bill that the Senate passed directs special derision at the National Science Foundation (NSF) by eliminating projects that the chairman of the Senate Appropriations Committee, Robert Byrd (Democrat, West Virginia), called "executive branch pork". legislative and public affairs at NSF. istration. nautics and Space Administration. Defense Initiative. frivolous. The Senate last week passed a bill

The projects include social science research on "Holism in psychobiology in the twentieth century" and biological research on "Sexual mimicry of swallowtail butterflies" and "Song production in freely behaving birds". In spite of their comic titles, the projects all passed rigorous scientific peer review, according to Ray Bye, director of

Research groups object to what they regard as Congress's patent disregard for the scientific process. "We and many others in the scientific community see this as an attack on the peer-review system", says Howard Silver, president of the Consortium of Social Science Associations. "It's the old Proxmire silly-title game carried one step further." Bye believes instead that science became an innocent victim of an electionyear feud between Congress and the admin-

A similar bill in the House of Representatives does not strike down any NSF projects, although it would take $\$ 5.8 \mathrm{mil}$ lion in unspecified funding from the $\mathrm{Na}$ tional Institutes of Health and \$4 million in research funding from the National Aero-

This week the Senate and the House were expected to meet in conference to reconcile the two versions, and research groups hope that the 'funny-titles' language will be deleted. But even if that attempt fails, the legislation could be vetoed by the president because it reduces funding for such favoured administration programmes as the Strategic

Christopher Anderson

\section{Einstein and Brandenburg}

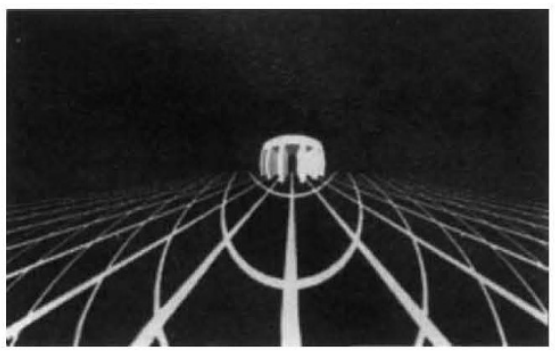

Flying through the Brandenburg gate at 99 per cent of the speed of light. The simulated distortion effect, demonstrating Einstein's Theory of Relativity, is created by one of the many interactive computers available for the amusement and education of visitors to the Deutsche Museum's new astronomy wing, opened last week in Munich.

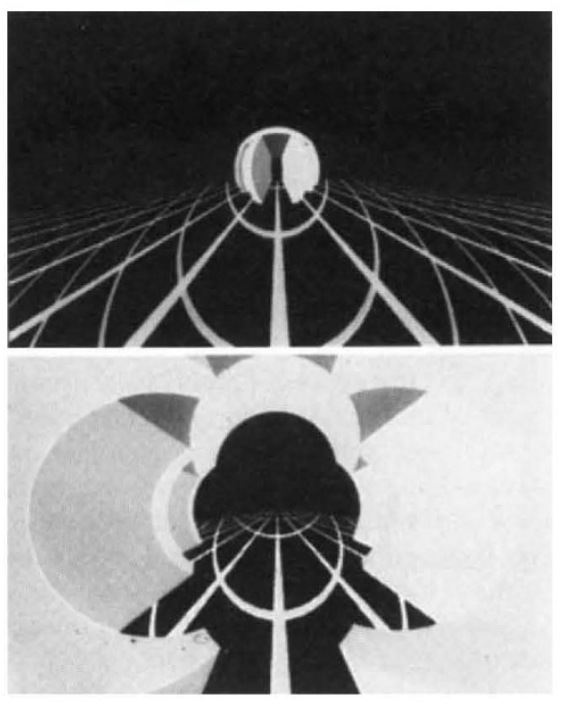

\section{Press sues to open White House science meetings}

Washington. A publishing group sued the US President's Council of Advisors on Science and Technology (PCAST) last week in an effort to force it to open its meetings to the public.

PCAST, a group of leaders from academic institutions and industry, provides advice to the White House through its Office of Science and Technology Policy. All but a few hours of its two-day monthly meetings are conducted in private.

The council has claimed that its deliberations qualify for exemptions to the US law that requires federal advisory committees to hold their meetings in the open. Arguing that most of PCAST's discussions are neither secret nor sensitive, the lawsuit contends that shielding the meetings from the public is illegal.

Bureau of National Affairs, Inc (BNA), a group that produces several science policy newsletters, initiated the suit. Nature and Science and Government Report, a biweekly newsletter published in Washington, have filed supporting affidavits and are co-plaintiffs.

The plaintiffs requested a temporary restraining order to halt a two-day meeting of PCAST held last week. At a hearing, Judge Thomas Hogan of the US District Court for the District of Columbia declined to stop the meeting, but ruled that its first day should be opened.

In defending its decision to close most of last week's meeting, PCAST claimed that parts of its discussions should be held in private because they dealt with personnel matters, a report in progress on the health of US universities and final reports on computing and biodiversity. All these topics, PCAST claimed, fall under exemptions to the federal law that requires open meetings. Another discussion on the UN global warming conference to be held next month in Rio de Janeiro needed to be kept confidential to avoid revealing details of the US negotiating strategy, it claimed.

Under the Freedom of Information Act, BNA requested records of previous meetings that had been closed and was able to obtain minutes of almost all the discussion. The fact that the minutes of PCAST meetings are publicly available casts doubt on the claim that the discussions should have been held in private, the plaintiffs argue.

The suit maintains that PCAST also routinely violates provisions that require it to announce its meetings 15 days in advance. Last week, PCAST gave three days notice, citing difficulties in arranging the schedules of participants. 